\title{
NEW HISPANIOLA LOCALITY RECORD FOR THE ENDEMIC BEETLE NICROPHORUS HISPANIOLA SIKES \& PECK, 2000 (COLEOPTERA: SILPHIDAE: NICROPHORINAE)
}

\author{
Daniel E. Perez-Gelabert
}

\begin{abstract}
Integrated Taxonomic Information System (ITIS).
Department of Entomology, National Museum of Natural History, Smithsonian Institution, P.O. Box 37012, Washington, DC 20013-7012, USA (e-mail: perezd@si.edu)
\end{abstract}

\begin{abstract}
The endemic Hispaniolan beetle Nicrophorus hispaniola Sikes \& Peck, 2000, is reported from the locality of Zapotén, Sierra de Bahoruco, Dominican Republic, a national park outpost near the border with Haiti. This species appears restricted to Sierra de Bahoruco and Sierra de Neiba in the southwestern corner of the Dominican Republic.
\end{abstract}

Keywords: Nicrophorus hispaniola, Silphidae, Sierra de Bahoruco, conservation.

Título: Nuevo registro de localidad en la Hispaniola para el escarabajo endémico Nicrophorus hispaniola Sikes \& Peck, 2000 (Coleoptera: Silphidae: Nicrophorinae).

\section{RESUMEN}

Se reporta el escarabajo endémico de la Hispaniola Nicrophorus hispaniola Sikes \& Peck, 2000, de la localidad de Zapotén, Sierra de Bahoruco, República Dominicana, una caseta de parques cercana a la frontera con Haití. Esta especie se restringe a la Sierra de Bahoruco y Sierra de Neiba, en la esquina suroeste de la República Dominicana.

Palabras clave: Nicrophorus hispaniola, Silphidae, Sierra de Bahoruco, conservación.

The endemic Hispaniolan burying beetle Nicrophorus hispaniola Sikes \& Peck, 2000 (Figs. 1A-C) is one of the most recently described species of the carrion beetle genus Nicrophorus Fabricius, being documented from several localities in the mountains of Sierra de Bahoruco and Sierra de Neiba, in southwestern Dominican Republic (Sikes \& Peck, 2000). Because silphid beetles are easily attracted to carrion traps, by the end of the $19^{\text {th }}$ century nearly all known species of Nicrophorus in the New World had already been described. Thus, the finding of $N$. hispaniola in an isolated region of the Dominican Republic in the 1990's was a welcome surprise to experts (Sikes \& Peck, 2000). Silphidae are commonly associated with carrion, fungi and dung and are useful in forensic entomology to determine post-mortem interval. These beetles are ecologically important, because with their burial behavior of carcasses they promote recycling of this organic material (Anderson \& Peck, 1985). Members of the subfamily Nicrophorinae characteristically have biparental care. There are 21 species of Nicrophorus in the New World, 15 from North America north of Mexico (one also present in Mexico) and five species from Mexico southward (Sikes \& Peck, 2000). Nicrophorus hispaniola is the only species known from the West Indies.

In this note, based on one male specimen, $N$. hispaniola is newly reported from the locality of Zapotén, Sierra de Bahoruco, Dominican Republic. This new site is located at about $5 \mathrm{kms}$ from the nearest previously known records. The rediscovery of this unique species provides another opportunity to call attention to the importance of preserving the rare ecosystems in the highlands of Sierra de Bahoruco. 
General recognition (Figs. 1A-C). Nicrophorine silphids are dorso-ventrally flattened beetles, antennae characteristically with a pubescent 3 -segmented club, antennal insertions on dorsal face of head, a large clypeus, a large scutellum, and a subapical bulge on each elytron. Nicrophorus hispaniola can be recognized by having antennae clubbed with apical three antennomeres yellowish-orange, pronotum orbicular in outline with greatest width across midline, elytron with a red anterior squared fascia and one posterior squared macula. Elytra covering only $2 / 3$ of abdomen, their posterior margin straight. In the key to New World Nicrophorus of Sikes \& Peck (2000) N. hispaniola is distinguished from its closest congeners by the colored anterior red elytral fascia that stretches laterally and the posterior elytral macula being large but not touching the elytral margin.

New record. One male, DOMINICAN REPUBLIC, Zapotén, Prov. Independencia, Sierra de Bahoruco, $18^{\circ} 18.707^{\prime} \mathrm{N} 71^{\circ} 42.467^{\prime} \mathrm{W}, 1540 \mathrm{~m}, 13-14 / \mathrm{ix} / 2014$, uv light \& night collecting, D. Perez. Deposited in the entomological collection of the National Museum of Natural History, Smithsonian Institution, Washington, DC (USNM) where this species was not previously represented. This specimen was collected at a UV lighted sheet during crepuscular to early night hours.

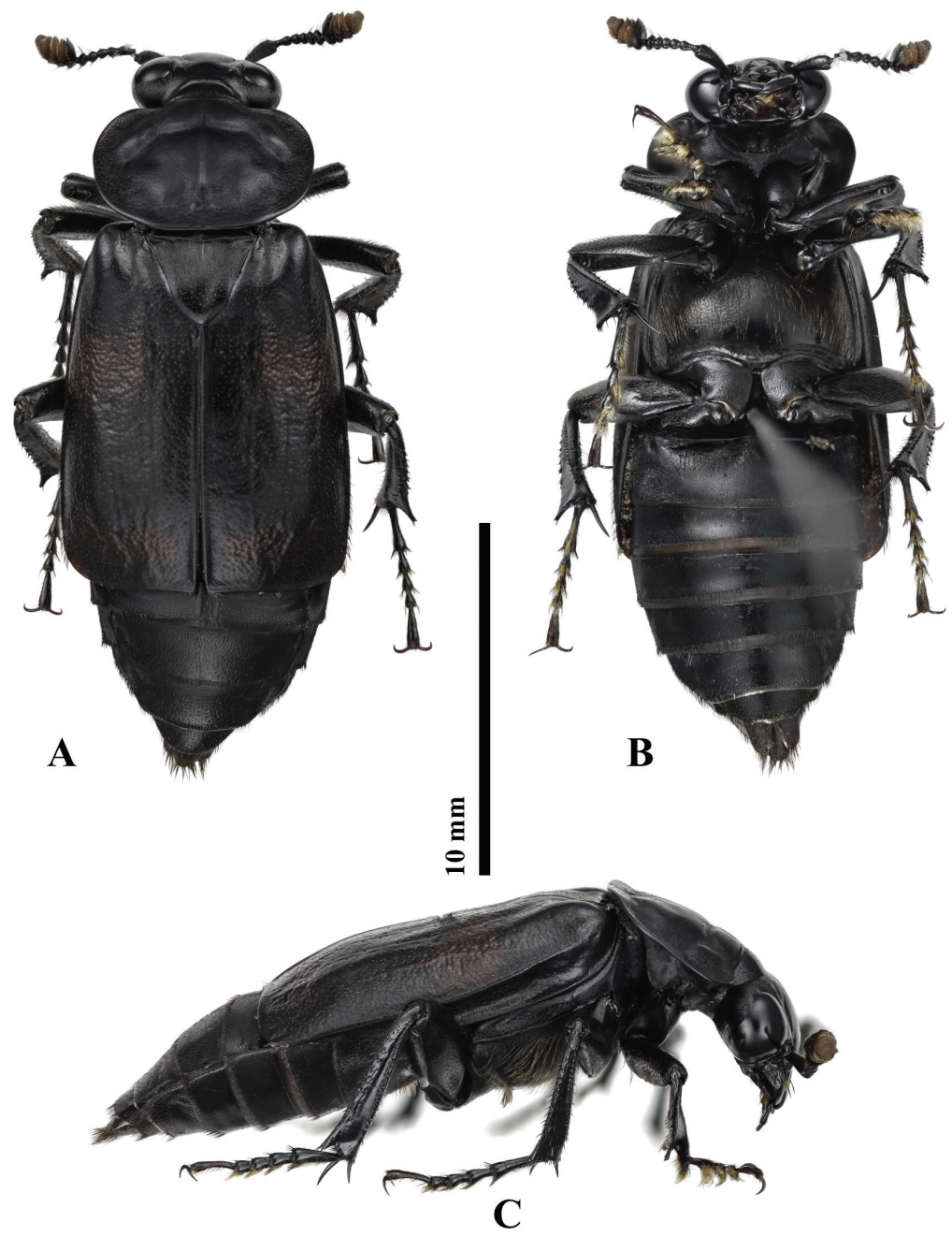

Figures 1A-C. Habitus pictures of male specimen of Nicrophorus hispaniola from Zapotén, Sierra de Bahoruco. A, dorsal, $\mathrm{B}$, ventral, C, lateral). 
Measurements. Body length: $21.0 \mathrm{~mm}$, maximum body width: $7.5 \mathrm{~mm}$, pronotum width: $6.0 \mathrm{~mm}$.

Comments. Previous collections of $N$. hispaniola were made between late June and early December. The new specimen was collected in September, so it falls near the middle of these dates. This species has been taken both from carrion traps and at black lights between $730-1930 \mathrm{~m}$ above sea level. The present specimen collection at $1540 \mathrm{~m}$ falls near the midpoint of these elevations. The forest at Zapotén is dominated by mountain pine (Pinus occidentalis) mixed with a variety of broadleaf vegetation. In contrast with the continental species of the genus which have large distributions, $N$. hispaniola appears to have the smallest distribution range of any New World species (Fig. 2), being restricted to the southwestern corner of the Dominican Republic, a region less than $100 \mathrm{~km}^{2}$ (Sikes \& Peck, 2000). This border region of Haiti and the Dominican Republic is a troubled habitat insufficiently protected even if located in a remote montane area and within a national park. This area of unique biodiversity must be saved from the ravages of poverty and indiscriminate exploitation by the producers of charcoal and squatting peasants that damage these forests. The Enriquillo-Bahoruco-Jaragua biosphere reserve, which includes this national park and two other adjacent parks, has been recognized as a region containing a very important representation of the biodiversity in the Dominican Republic, including a large number of threatened endemic species (León et al., 2011). This unique beetle is a rare species potentially threatened with extinction. As commented by its describers, such species possessing unique morphological characteristics are very important for phylogenetic studies (e.g., Sikes \& Venables, 2013) to better understand the evolution of the whole group. The divergence data analysis of Sikes \& Venables (2013) estimated that the speciation event that resulted in $N$. hispaniola splitting from its sister species $N$. pustulatus occurred between 35-15 million years ago. It would be interesting to investigate whether $N$. hispaniola is also a parasitoid of snake eggs as it has been documented for N. pustulatus (Smith et al., 2007). The conservation status of $N$. hispaniola should be further investigated and its conservation should become a priority in the park management plans.

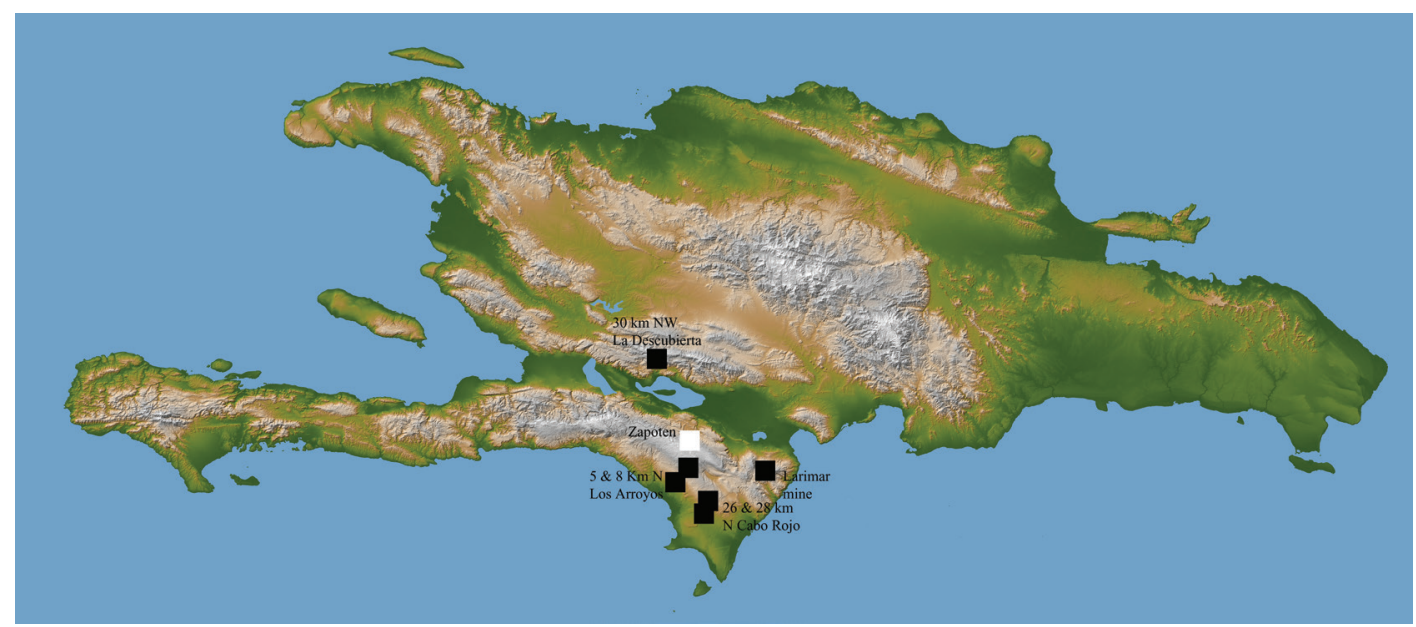

Figure 2. Map of Hispaniola showing the approximate distribution of localities at which Nicrophorus hispaniola has been collected. 


\section{ACKNOWLEDGMENTS}

Michael A. Ivie (Montana State University, Bozeman) called my attention to this unique beetle. Stewart B. Peck (Carleton University, Ontario, Canada) and Derek S. Sikes (University of Alaska) provided useful suggestions and input on the manuscript. Karie Darrow (Department of Entomology, USNM) produced the habitus pictures.

\section{LITERATURE CITED}

Anderson, R. S. \& S. B. Peck. 1985. The Carrion Beetles of Canada and Alaska. Coleoptera: Silphidae and Agyrtidae. The Insects and Arachnids of Canada, part 13. Biosystematics Research Institute, Ottawa, Ontario, Research Branch, Agriculture Canada. 121 pp.

León, Y. M., E. Rupp, Y. Arias, L. Perdomo, S. Incháustegui \& E. Garrido. 2011. Estrategia de Monitoreo para Especies Amenazadas de la Reserva de Biosfera Enriquillo-BahorucoJaragua. Grupo Jaragua, Santo Domingo, República Dominicana. ii + 91 pp.

Sikes, D. S. \& S. B. Peck. 2000. Description of Nicrophorus hispaniola, new species, from Hispaniola (Coleoptera: Silphidae) and a key to the species of Nicrophorus of the New World. Annals of the Entomological Society of America 93: 391-397.

Sikes, D. S. \& C. Venables. 2013. Molecular phylogeny of the burying beetles (Coleoptera: Silphidae: Nicrophorinae). Molecular Phylogenetics and Evolution 69: 5522-565.

Smith, G., S. T. Trumbo, D. S. Sikes, M. P. Scott \& R. L. Smith. 2007. Host shift by the burying beetle, Nicrophorus pustulatus, a parasitoid of snake eggs. Journal of Evolutionary Biology 20: 2359-2399.

[Recibido: 05 de agosto, 2016. Aceptado para publicación: 01 de septiembre, 2016] 